\title{
Peranan Mashlahah Mursalah dan Pembaharuan Hukum Islam di Indonesia
}

\author{
Barmawi Mukri
}

The concept of mashlahah mursalah (unrestricted interests) is among the most popular models of classical legal reasoning. This because, the reasons accommodated in this legal reasoning is the consideration to gain the good and avoid the bad in human life. Therefore, compared to others, according to the writer, mashlahah is the most suitable and relevant legal reasoning to implement in Indonesian Islamic legal reform.

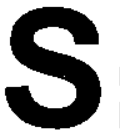

umber hukum Islam ada tiga macam, yaitu al-Qur'an, Sunah Rosul dan ijtihad (ar-ra'yu). Hal ini didasarkan pada hadits Nabi riwayat Ahmad Ibnu Hambal' dan juga diriwayatkan Abu Dawud, Turmudzi dan al-Baihaqi, yaitu ketika shahabat Mu'adz bin Jabal diutus Nabi ke Yaman, Nabi bertanya kepada Muadz "apa yang akan kamu lakukan jika diajukan kepadamu suatu perkara untuk diputuskan ?". Jawab Mu'adz, "saya akan putúskan perkara itu berdasarkan ketentuan dalam al-Qur'an. Lalu Nabi bertanya lagi, "bagaimana jika kamu tidak mendapatkan ketentuannya dalam al-qur'an?". Jawab Mu'adz,"saya akan memutuskan perkara itu berdasarkan ketentuan dalam sunah Rasulullah". Kemudian Nabi melanjutkan bertanya, " bagaimana jika kamu tidak mendapatkan ketentuan dalam Sunah Rasulullah?". Mu'adz menjawab," saya akan berijtihad menggunakan pikiranku, dan tidak akan aku biarkan perkara itu tanpa putusan apapun. Mu'adz mengatakan, bahwa Nabi kemudian menepuk dadaku dan beliau bersabda: "Alhamdulillah, segala puji bagi Allah yang memberikan taufiqnya kepada utusan Rasulullah dengan sesuatu hal yang melegakan Rasulullah".
Dari hadits Mu'adz bin Jabal di atas dapat diketahui bahwa sumber hukum yang pertama adalah al-Qur'an, kedua adalah Sunah Rasulullah dan ketiga adalah ar-ra'yu (ijtihad). Artinya adalah pemakaian pikiran atau ijtihad baru boleh digunakan jika dalam suatu masalah tidak ada ketentuan yang jelas dari al-Qur'an dan Sunah Rasulullah.

ljtihad adalah suatu pekerjaan mempergunakan segala daya upaya pikiran dari seorang mujtahid untuk memperoleh ketentuan hukumnya suatu perkara yang tidak diatur dan al-Qur'an maupun sunah Rasulullah. Jadi ijtihad menggunakan pikiran (ar-ra'yu) untuk memperoleh ketentuan hukum itu dibenarkan berdasarkan hadits Mu'adz bin Jabal di atas. ljtihad yang dilakukan seseorang disebut litihad Fardi, sedangkan ijtihad yang dilakukan oleh sekelompok orang disebut litihad Jama'i. Dalam jitihad mempunyai beberapa metode, yaitu ijtihad dengan Qiyas, Istihsan, Istishhab ,Uruf dan Maslahah Mursalah.

1 Ahmad bin Hambal, Musnad Ahmad bin Hambal, Juz 5, (Beirut al-Maktabah, alislamiyah, t.th), hlm 236. 


\section{Dinamika Hukum Islam dan Peran Maslahah Mursalah}

Dengan diakuinya lembaga ijtihad dengan berbagai metodenya, maka menjadikan hukum Islam yang bersifat ijtihadi menjadi lebih dinamis dan kontekstual, tidak ketinggalan zaman, karena perkara-perkara yang baru yang belum ada ketentuan hukumnya dalam alquar'an maupun hadits Nabi akan selalu dapat ditentukan hukumnya dengan jalan ijtihad, atau masalah-masalah yang lama yang sudah ditentukan hukumnya dengan jalan ijtihad tetapi tidak berlaku lagi secara efektif dalam masyarakat, karena perkembangan zaman sudah berlainan, maka terhadap masalah-masalah lama itu dapat ditentukan atau dirubah ketentuan hukumnya sesuai dengan zamannya dengan dasar pertimbangan yang lebih manfaat dan maslahat sepanjang dibenarkan syara'.

Pemberdayaan hukum dengan yang lebih realistis dan aktual dibenarkan oleh syara' jika alasan-alasan yang lebih bermanfaat bagi kehidupan umat. $\mathrm{Hal}$ ini sesuai dengan kaidah-kaidah figh yang terkait misalnya:2

"Taqhayyul Fatwa wa ikhtila fuha bihasbi taqhayyuril azminati wal amkinati wal ahwali wal "awa "id"

Artinya: Bahwa perubahan fatwa dan perbedaannya dikarenakan adanya perubahan waktu, tempat, keadaan atau adat. ${ }^{3}$

"La yunkaru taqhaiyyurul ahkami bi taqhaiyyuril azminati wal amkani"

Artinya: Tidak dimungkiri terjadinya perubahan hukum karena perubahan zaman dan tempat. ${ }^{4}$

"Al-hukmu yaduru ma'a 'illatihi wujudan wa 'adaman"

Artinya: Hukum itu dapat beredar (berubah) berdasarkan ada tidaknya illat.

Dari qaidah-qaidah fiqh di atas dapat diambil kesimpulan bahwa hukum Islam yang bersifat ijtihadi, yang berkaitan dengan masalah keduniawian atau mu'amalat dapat berubah-ubah sesuai dengan perubahan zaman atau tempat sepanjang ada alasanalasan hukum (illat) yang melatar belakanginya, atau ada kebutuhan yang mendesak yang lebih maslahat bagi kehidupan umat.

Kalau dianalisa lebih lanjut dapat dipahami bahwa hukum yang ditetapkan Allah dalam al-Qur'an atau yang telah dikemukakan Rasulullah melalui haditshaditsnya tujuannya tidak lain adalah untuk mendatangkan kemasiahatan hidup umat manusia, baik dalam sifatnya yang memberikan manfaat atau yang menghindarkan kerusakan (madharat). Semua masalah yang mendatangkan manfaat menurut al-Qur'an atau hadits Nabi, tentu hukumnya diwajibkan, dianjurkan atau diperbolehkan untuk diamalkan. Sebaliknya, jika suatu masalah mendatangkan madharat atau kerusakan bagi diri seseorang, tentu hukumnya dimakhruhkan atau diharamkan.

Terhadap masalah-masalah yang tidak ada dalil nash, baik dari al-Qur'an maupun hadits yang memerintahkan atau membatalkan, maka terhadap masalah tersebut dapat ditetapkan hukumnya dengan jalan ijtihad, yakni dengan metode maslahah mursalah atau istislah dan lain-lain.

Perkataan "maslahah mursalah" berarti hukum yang tidak ada dalilnya yang

2 Ibnul Qoyyum I'lamul Muwaqi'in, Juz III (Beirut), Darul Jail, t.t), hlm.3.

3 Asymuni A.Rahman, Qa'idah-qa'idah Fiqih, (Jkt, Bulan Bintang, 1976), hlm. 107.

4 ibid, hlm. 71, dar T.M. Hasbi AshShiddieqy, Falsafah Hukum Islam, cet.1, (Jakarta, Bulan Bintang, 1988), hlm. 282. 
membenarkan atau mendukungnya, sementara itu juga tidak ada dalil yang membatalkan, tetapi merupakan hukum yang ditetapkan atas pertimbangan prinsip mendatangkan manfaat dan menolak madharat.

Ulama Usul Fiqh bervariasi dalam memberikan terminologi terhadap mashlahah murshlalah. Ma'ruf Ad-Dawalibi memberikan definisi bahwa" Istishlah pada hakikatnya adalah satu macam hukum yang dihasilkan dengan (ijtihad) bir-ra'yi (pikiran) yang dibangun atas dasar kemashlahatan. ${ }^{5}$ Sementara itu Abdul Wahhab Khallaf, memberikan definisi mashlahah murshalah sebagai berikut:"Menetapkan hukum suatu masalah yang tidak ada nashnya dan tidak ada ijma' terhadapnya, tetapi hukum itu dibangun berdasarkan mashlahat yang tidak ada dalilnya dari pihak syari' (pembuat hukum yaitu Allah dan Rasulnya) baik itu yang membenarkan atau membatalkannya. ${ }^{6}$

Dari terminologi mashlahah murshlalah di atas dapat disimpulkan bahwa penetapan hukumm dengan jalan mashlahan murshlalah merupakan a way out atau pemecahan masalah hukum yang timbul dalam masyarakat yang tidak ada ketetapannya (nashnya) dalam al-qur'an maupun hadits Nabi, yang kemudian masalah itu ditetapkan dengan ijtihad yang berprinsip pada pertimbangan bahwa ketetapan itu akan mendatangkan manfaat dan maslahat sesuai yang dibenarkan syara'.

Ulama yang berpedoman pada mashlahah murshlalah sebagai metode untuk menetapkan hukum adalah Imam Malik bin Anas, Imam Ahmad bin Hanbal, Imam Ath-Thufi dan Ibnu Taimiyah.

Adapun dasar hukum yang digunakan mereka dalam berpedoman pada mashlahah murshlalah adalah sebagai berikut:
Pertama: Dalil nash dari al-Qur'an yaitu Q.S al-Baqarah (2): 185, Q.S. alMa'idah (5): 6, dan Q.S an-Nahl (16): 90. Ayat-ayat al-Qur'an pada intinya menjelaskan bahwa hukum Islam itu gampang, tidak mempersulit atau tidak mempersukar hidup umat manusia, tetapi prinsipnya hukum Islam adalah untuk menciptakan kemashlahatan hidup umat manusia. Hal ini sesuai dengan pendapat Abdul Wahhab Khallaf, yang menyatakan bahwa tujuan secara umum Allah dan Rasulnya sebagai Asy-Syari' memberlakukan (tasyri' kan) hukumnya adalah untuk menciptakan kemashlahatan umat manusia di dalam hidupnya. ${ }^{7}$

Kedua: Dalil nash dari hadits Nabi antara lain hadits Mu'adz bin Jabal seperti yang disebutkan dalam permulaan tulisan ini, yang membolehkan ijthad bir-Ra'yi (pikiran) manakala suatu masalah tidak ada dalilnya dari al-qur'an maupun hadits $\mathrm{Nabi}$.

Di samping itu ada hadits lain yang berbunyi "La dharara wa la dhirara, ${ }^{8}$ artinya tidak boleh berbuat sesuatu yang membahayakan dirinya sendiri dan membahayakan orang lain.

Oleh Imam ath-Thufi, hadits ini dijadikan dasar keabsahan menggunakan metode mashlahah murshlalah. Dalam hadits ini

${ }^{5}$ Muh. Ma'ruf ad-Dawahbi, al-Madkhal ila'llmi Ushulul Figh, cet.1 (Damaskus, Darul Kutub, 1965), hlm. 282.

${ }^{6}$ Abdul Wahhab Khallaf, Mashadirul /slami fi ma la nashsha fihi, cet.5 (Kuwait, Darul Qalam, 1961), him. 65.

${ }^{7}$ Abdul Wahhab Khallaf, Ilmu Usulul Fiqih, cet. 8, (Kairo, Darul Kuwait, 1968), hlm. 198.

${ }^{8}$ An Nawawi, Yahya bin Syarifuddin Matan al-Arba'in Nawawiyah, (Cirebon, Syirkah Math, ba'ah Indonesia, t.th), hlm. 52. Hadis ini bernilai hasan dan diriwayatkan oleh lbnu Majah dan ad-Daru Quthni dari Abu Sa'id alKhudry. 
menurut beliau dapat diambil kesimpulan bahwa menghilangkan madharat dalam rangka mewujudkan kemashlahatan wajib didahulukan. ${ }^{\ominus}$ Hadits ini sesuai dengan Q.S al-A'raf (2): 55 , yang artinya janganlah kamu berbuat kerusakan di atas bumi setelah diperbaiki. Hadits inipun sesuai dengan qaidah fiqh: ${ }^{10}$

Artinya: Menolak kerusakan itu didahulukan dari mengambil mashlahat.

Ketiga: Amal Shahabat. Di antara para sahabat yang mengamalkan prinsip mashlahah dalam menetapkan hukum adalah Abu Bakar dan Umar bin al-Khathab. Abu Bakar r.a pernah melakukan inisiatif untuk mengkodifikasikan al-Qur'an karena banyaknya para shahabat yang hafal alQur'an gugur dalam peperangan melawan orang-orang murtad yang ingkar membayar zakat dan dalam peperangan melawan orang-orang yang mengaku dirinya sebagai Nabi. Demikian pula Umar bin al-Khathab pernah memutuskan bahwa orang yang menceraikan isterinya dengan talak tiga kali sekaligus tetap jatuh talak tiga meskipun diucapkan dalam satu majelis sekali. Demikian pula Umar memberi fatwa pencuri yang mencuri dalam keadaan paceklik (krisis pangan) tidak diberi hukuman potong tangan."

Keempat: Dalil Akli. Jika suatu masalah harus ditetapkan dengan metode mashlahah murshlalah, maka nilai mashiahatnya harus rasional (masuk akal), artinya hukum yang ditetapkan dangan akal sehatnya itu pasti akan bernilai manfaat dan dapat menolak madharat serta tidka bertentangan dengan tujuan syara'. ${ }^{12}$

Imam Asy-Syathibi dalam kitab alI'tisham menetapkan tiga syarat dalam pemakaian mashlahah, agar selalu dapat dibenarkan syara' yaitu:
1) Adanya persesuaian antara mashlahat yang dijadikan dasar pertimbangan penetapan hukum dengan maksud syara' yang umum, sehingga tidak mungkin akan berlawanan dengan salah satu aturan pokok atau dalil qath'i dalam al-qur'an maupun hadits. Sementara mashlahat itu harus termasuk dalam jenis mashlahat umum, yang hendak dicapai oleh syara', meskipun tak ada dalil khusus untuk itu.

2) Mashlahat yang dipertimbangkan sebagai dalil (dasar illatnya) itu harus masuk akal, sehingga apabila diajukan kepada orang-orang yang berpikir pasti akan menerimanya.

3) Pemakaian metode mashlahat itu benar-benar akan menghindarkan kesempitan dalam agama, sebaliknya jika mashlahat itu tidak digunakan tentu akan menimbulkan madharat atau kesulitan bagi orang banyak. ${ }^{13}$

Dalam rangka pemakaian metode mashlahah yang lebih akurat dan tepat sasaran, maka disamping harus mengacu kepada syarat-syarat sebagaimana yang telah dikemukakan dalam Imam AsySyatibi, juga harus selalu diperhatikan seberapa qiadah-qaidah fiqhiyah sebagai berikut:

${ }^{9}$ Lihat lebih lanjut dalam Sulaiman Ibnu Abdul Qowwi, dalam al-Mushlahah fi Tasy-Ri'i Islami wa Nayamuddin Ath-Thufi, (t.t.p, Musthafa Zaid, t.t), hlm.67-77.

to Asyamsi A.Rahman, Qa'idah-qa'idah , hlm. 75.

91

11 Abdul Wahhab Khalaf, Mashadir, hal.

12 Ibid, hlm. 102

13 A.Hanafi Pengantar dan Sejarah Hukum Islam, cet. 4 (Jakarta, Bulan Bintang, 1984)hlm. 84. 
(Al-Masyaqqatu tajlibut taisir)

Artinya: Bahwa kesukaran itu dapat menarik kemudahan.

(Dar'ul Mafasid Aula min jalbil mashalih)

Artinya: Menolak kerusakan itu lebih didahulukan dari menarik kemashlahatan.

(Al-hajatu tanzilu manzilat dharurati ammatan kanat au khashatan)

Artinya: Kebutuhan itu dapat menempati kedudukan dharurat baik secara umum atau khusus. ${ }^{14} 15$

(Al-Hukmu yaduru ma'a illatihi wujudan wa 'adaman)

Artinya: Hukum itu dapat berubah karena ada tidaknya illat (yang melatar belakanginya). ${ }^{16}$

(Tasharruful Imami 'alar-Ra'iyyati manuthum bil mashlahati)

Artinya: Tindakan penguasa terhadap rakyatnya harus dihubungkan dengan kemashlahatan.

Berikut ini akan dikemukakan contohcontoh pembaharuan hukum Islam yang masuk dalam perundang-undangan negara R.l yang dilakukan dengan dasar mashlahah, yaitu antara lain:

Pertama, kepemilikan atas tanah bisa terjadi karena warisan, hibah, jual beli, tukar guling, atau dengan membuka tanah baru yang belum dimiliki oleh seseorang. Karena sesuatu hal, kepemilikan atas tanah sering menimbulkan perselisihan. Oleh karena itu tidaklah salah jika pemerintah mengeluarkan UU No. 5 Th. 1960 tentang pokok agraria yang di dalamnya ada ketentuan tentang wajibnya pendaftaran hal milik atas tanah agar kelaknya si pemilik tanah tersebut dapat memperoleh sertifikat tanah sebagai tanda bukti otentik kepemilikan tanah yang sah.

Kedua, jika seseorang akan mewakafkan tanah harus mengikrarkan kehendaknya secara jelas dan tegas kepada nadzir di hadapan Pejabat Pembuat Akte Ikrar Wakaf dalam bentuk ikrar wakaf dengan disaksikan sekurang-kurangnya 2 orang saksi. Demikian bunyi pasal 218 ayat (1) KHI. Kemudian setelah ikrar wakaf dilaksanakan sesuai dengan ketentuan dalam pasal 223 ayat (3) dan (4), maka Kantor Urusan Agama Kecamatan atas nama Nadzir yang bersangkutan diharuskan mengajukan permohonan kepada Camat untuk mendaftarkan perwakafan tanah (benda) yang bersangkutan guna menjaga keutuhan dan kelestariannya.

Demikian pada $244 \mathrm{KHI}$ pendaftaran benda wakaf itu dimaksudkan agar nadzir dapat bertanggung jawab menjaga keutuhan dan kelestarian benda wakaf dan ia sendiri dengan. sertifikat wakaf itu dalam pengelolaan dapat jaminan dan kepastian hukum. Jadi pendaftaran benda wakaf ini dimaksudkan untuk lebih mendatangkan manfaat dan menolak madharat.

Ketiga, dalam kitab-kitab fiqh tentang pencatatan perkawinan tidak termasuk syarat sahnya perkawinan. Kemungkinan besar para ulama pada saat itu belum menganggap pencatatan perkawinan itu penting dan bermanfaat. Di sisi lain, pencatatan erkawinan tidak dilarang dalam Islam bahkan mendatangkan mashlahat yang banyak seperti untuk ketertiban, kepastian hukum dan mencegah terjadinya perkawinan monogami atau poligami yang

${ }^{14}$ Keiga qa'idah Fiqhyah itu lihat AsSuyuthi, al-Asybah wan Nadzair, cet. 3 (Mesir, Amin Abdul Majid, 1960), hIm. 55 dan 62.

15 Hasbi Ash-Shiddieqy, Falsafah Hukum ,hlm 282.

${ }^{16}$ Asymuni A.Rahman, Qa'idah-qa'idah Fiqih , hlm. 1 (Jakarta, Bulan Bintang, 1976), hlm. 60 . 
liar. Oleh karena dengan pertimbangan mashlahah mengharuskan adanya pencatatan perkawinan seperti tersebut dalam UU No. 1 Th. 1974, pasal 2 ayat (2) dan pasal 5 ayat (1) dan ayat (2) KHI. Dalam pasal 5 ayat (1) KHI jelas-jelas disebutkan “ agar terjamin ketertiban perkawinan bagi masyarakat, sehingga setiap perkawinan harus dicatat".

Keempat, dalam kitab-kitab fiqih tidak ada larangan anak-anak di bawah umur melakukan perkawinan melalui walinya sebab hal itu tidak ada nash al-Qur'an maupun hadits Nabi yang melarangnya.

Untuk kebaikan pihak-pihak yang berkepentingan langsung dengan perkawinan itu, seperti wali, calon suami, dan isteri serta agar tujuan perkawinan itu dapat tercapai, maka atas dasar untuk mashlahah murshalah, pemerintah dapat membuat aturan yang berisi larangan terjadinya perkawinan anak-anak misainya dengan mambuat aturan tentang batas umur nikah, ${ }^{17}$ seperti dalam pasal 7 ayat (1) UU No.1 Th. 1974 dan pasal $15 \mathrm{KHI}$.

Kelima, asas perkawinan dalam Islam adalah sekali dilakukan perkawinan untuk selama-lamanya. Oleh karena itu Islam mempersukar perceraian yang mempunyai dampak negatif bagi kedua suami isteri yang bercerai, bergitu pula bagi anak-anak mereka. Dalam hal ini hadits Nabi riwayat Abu Dawud dan Ibnu Majah mengajarkan bahwa hal yang halal tetapi paling dibenci Allah adalah talak. ${ }^{18}$

Dalam kitab figh disebutkan bahwa cerai dapat terjadi dengan mudah, bisa dijatuhkan dengan ucapan dan tulisan. Tidak perlu itu melalui proses pengadilan sehingga banyak sekali terjadi kesewenang-wenangan suami dalam menjatuhkan talak tanpa memperhatikan hak-hak isteri yang dicerai.

Oleh karena itu jika kemudian pemerintah mengatur perceraian melalui proses pengadilan dan pembuktian yang teliti tentang alasan-alasan cerai apakah cukup kuat atau tidak sebagaimana yang diajukan oleh suami atau isteri, tentu dibenarkan jika didasarkan pada pertimbangan mashlahah murshlalah. Apalagi jika setelah proses persidangan, pengadilan bertindak sebagai hakam (juru damai) terhadap suami atau isteri yang mau bercerai itu. Dengan berfungsinya Pengadilan sebagai hakam tidak sedikit suami isteri yang mengurungkan niatnya untuk bercerai.

Pasal 39 dan 40 UU No. 1 Th 1974 adalah pasal-pasal tentang perceraian dan gugatan perceraian yang harus diajukan melalui Pengadilan. Dalam KHI tentang tata cara perceraian itu diatur dalam pasal 127148. Dalam pasal 39 UU No. 1 Th. 1974 , juga dinyatakan bahwa perceraian hanya dapat dilakukan di depan sidang Pengadilan setelah Pengadilan yang bersangkutan berusaha dan tidak berhasil mendamaikan kedua belah pihak. Jadi dari isi pasal di atas dapat diketahui bahwa perceraian yang dilakukan di depan sidang pengadilan itu lebih mashlahat dan lebih punya hikmah yang banyak.

Keenam, dalam kitab-kitab figh tidak ada ketentuan yang mengatur harta bersama dalam perkawinan, yang diatur hanyalah harta bawaan masing-masing suami dan isteri, baik yang diperoleh sebagai hadiah, hibah atau warisan sebelum atau sesudah perkawinan. Kalau isteri dicerai oleh suami, dia hanya memperolah nafkah 'iddah atau mut'ah dari suami yang bertanggung jawab. Tetapi jika suami itu seorang yang tidak

${ }^{17}$ A. Azhar Basyir, Hukum Perkawinan Islam, cet. 3 (Yogyakarta, Fakultas Hukum UII, 1980), hlm. 14.

18 ibid, hlm. 64. 
bertanggung jawab, maka bekas isteri itu tidak menerima hak-haknya sama sekali. Selain itu, jika suami sukses bekerja sehingga memperoleh hasil kekayaan yang lumayan, maka kesuksesan itu hanya semata-mata hasil usaha dan jerih payah suaminya. Jika suaminya saja yang bekerja isteri dianggap tidak mempunyai andil sama sekali, walaupun andil itu hanya sebatas dorongan moral bagi suami. Padahal dorongan moral isteri terhadap suami dalam bekerja mempunyai peranan penting bagi sukses atau tidaknya pekerjaan suami. Oleh karena itu lebih mashlahah jika suami dan isteri hakikatnya bersekutu (berserikat) dalam memenuhi kebutuhan-kebutuhan rumah tangga, meskipun secara realitas suami sendiri yang secara perseorangan adalah yang bekerja.Kemudian perlu diketahui bahwa lembaga harta bersama dalam perkawinan sudah hidup mengakar dalam masyarakat sebagai hukum adat.

Atas dasar pertimbangan mashlahah murshlalah maka dibenarkan jika pemerintah mengatur melalui undang-undangnya agar jsteri yang dicerai atau ditinggal mati itu memperoleh separoh dari harta bersama dalam perkawinan yang dijadikan modal dalam memulai membangaun rumah tangga secara single parent, dan tidak terjerumus melakukan hal-hal yang madharat. Mengenai masalah harta bersama dalam perkawinan itu telah diatur dalam pasal 35 ayat (1) dan pasal 36 ayat (1). Dalam KHI diatur dalam BAB XIII, pasal 85-97.

Ketujuh, dalam hukum Isiam terdapat ketentuan bahwa anak angkat tidak berhak mewarisi harta peninggalan orang tua angkatnya. Demikian pula orang tua angkat tidak berhak mewarisi harta peninggalan anak angkatnya yang mati, meskipun keduanya sama-sama beragama Islam kecuali dengan jalan wasiat.
Dalam adat kebiasaan yang hidup dalam masyarakat, suami dan isteri yang mengadopsi anak adalah disebabkan karena mereka tidak dikaruniai anak (keturunan). Bahkan banyak sekali, mereka mengadopsi anak sejak dari bayi, dan anak yang diadopsi itu masih mempunyai hubungan famili dengan salah seorang suami atau isteri itu. Oleh karena itu, tidak mengherankan jika mereka memposisikan diri sebagai orang tua sungguhan dengan tanggung jawab yang penuh dalam mengasuh, mendidik dan memelihara anak angkatnya. Demikian pula anak angkatnya itu, walau mengetahui bahwa sebagai anak yang diadopsi, tetapi kebaktian dan kesetiaan dia kepada kedua orang tua angkatnya seperti kepada orang tua biologisnya.

Oleh karena itu, atas dasar pertimbangan mashlahah murshlalah, jika seandainya anak angkat tidak memperoleh wasiat dari orang tua angkatnya, atau sebaliknya orang tua angkat tidak memperoleh wasiat dari anak angkatnya, maka mereka itu dapat memperoleh bagian warisan atas dasar wasiat wajibah dan maksimal bagiannya $1 / 3$ (sepertiga) dari harta warisan orang tua angkatnya atau anak angkatnya. Oleh karenanya tepat bahwajika orang tua angkat atau anak angkat yang tidak menerima wasiat, mereka diberi wasiat wajibah sebanyak-banyaknya $1 / 3$ dari harta peninggalannya. Hal ini diatur dalam pasal $209 \mathrm{KHI}$.

Kedelapan, umat Islam sudah lama mengenal lembaga wakaf. Dalam praktiknya wakaf pada sebagian besar umat lsiam baru terbatas pada perwakafan benda tak bergerak, seperti tanah yang.dipergunakan untuk bangunan masjid, tempat pendidikan, rumah sakit, dan lain-lain atau hasil tanah itu untuk pemeliharaan bangunan-bangunan tersebut. 
Mereka mempunyai pendirian yang kuat bahwa benda wakaf itu haruslah benda yang tidak habis dipakai, yang kekal abadi (tidak hancur). Mereka berpendirian seperti itu karena sebagian besar umat Isiam Indonesia bermadzab Syafi'i, walaupun ulama syafi'iyah pada dasarnya memperbolehkan wakaf berupa benda bergerak dan tidak bergerak asal tidak cepat habis (hancur) jika digunakan. ${ }^{19}$

Pada saat ini, obyek wakaf baik itu berupa wakaf benda tetap atau benda tak tetap, sudah saatnya untuk lebih diberdayakan agar lebih produktif, misalnya wakaf yang berupa tanah atau rumah diberdayakan untuk disewakan, wakaf hewan untuk diternakkan, dan wakaf uang untuk modal investasi, sehingga diharapkan kelaknya dapat menciptakan kemashlahatan umat yang lebih luas jika disertai pengelolaan nadzir yang profesional. Hasilnya untuk dana pembangunan seperti untuk pembangunan jalan-jalan, selokan, tempat ibadah, memajukan dunia pendidikan dan untuk memperbaiki kesejahteraan hidup masyarakat.

Dalam kaitan ini bahkan M. Anwar Ibrahim lebih menekankan pemberdayaan wakaf dengan uang karena manfaatnya lebih besar dari, wakaf tradisional yang berupa benda tak bergerak atau benda bergerak. Di samping itu, wakaf dengan uang lebih banyak dapat dilakukan oleh orang. Jika wakaf uang dapat dikelola secara profesional oleh nadzir sebagai lambaga pengelola wakaf, maka akan menjadi modal usaha yang besar. ${ }^{20}$

Selanjutnya Anwar Ibrahim menjelaskan bahwa MUI pusat telah mensyahkan wakaf uang berdasarkan Keputusan Komisi Fatwa MUI Pusat tanggal 11 Mei 2003. Dalam fatwanya dikemukakan bahwa wakaf uang adalah wakaf yang dilakukan seseorang, kelompok orang, lembaga atau badan hukum dalam bentuk uang tunai, termasuk dalam pengertian uang adalah surat-surat berharga. Hukum wakaf dengan uang itu dibolehkan (jaiz) asalkan nilai pokok wakaf uang itu tidak boleh dijual, dihibahkan atau diwariskan dan penggunaannya harus untuk hal-hal yang dibolehkan oleh syara'. ${ }^{21}$ Fatwa MUi Pusat lewat Komisi Fatwanya tentang kebolehan wakaf dengan uang tunai itu sesuai dengan pendapat Imam Az-Zuhri (W. Th $124 \mathrm{H}$ ) yang membolehkan wakaf dalam bentuk uang, yang waktu itu uang berupa dinar dan dirham. ${ }^{22}$

Sudah dapat dipastikan bahwa pemberdayaan wakaf pada yang lebih produktif akan termuat dalam RUU wakaf yaing telah diajukan Pemerintah, dalam hal ini Departemen Agama ke DPR RI akhir Januari 2003.RUU wakaf ini terdiri $11 \mathrm{Bab}$ dan 32 pasal. Pada Bab VI berisi tentang pengembangan dan pemberdayaan wakaf, sedangkan pada Bab VII berisi tentang Perubahan, Penyelesaian Perselisihan dan Pengawasan Perwakafan.

\section{Penutup}

Dari uraian di atas dapat disimpulkan:

1. Bahwa metode ijtihad dengan mashlahah murshlalah adalah metode yang paling efektif digunakan dalam menetapkan hukum atau pembaharuan hukum Islam dalam perundangundangan di Indonesia.

${ }^{19}$ Abu Zahrah, Muhadharah fil Waqhi, (t.t.p., Darul Fikri al-Araby, 1971)hlm.104.

20 M. Anwar Ibrahim dalam Memberdayakan Lewat Wakaf, Tabloid Jum'at tgl 4 April 2003, him. 4.

21 lbid

${ }^{22}$ Didin Hafiduddin, dalam Wakaf Tunai Kenapa Tidak, (Republika, Jum'at, 17 Mei 2003), hlm. 4. 
Topik: Peranan Mashlahah Mursalah dan Pembaharuan..., Barmawi Mukri

2. Bahwa pembaharuan hukum Islam yang sudah eksis dalam perundangundangan baru sebatas pada hukum perdata Islam.

3. Bahwa salah satu pemasukan keuangan negara yang vital adalah wakaf. Pemberdayaan wakaf kepada yang lebih produktif sudah saatnya dimasukkan dalam perundangundangan di Indonesia dan kemanfaatannya lebih luas lagi bagi kehidupan umat, nusa dan bangsa.

\section{Daftar Pustaka}

Abdurarrahman, M,1992, Kompilasi Hukum Islam di Indonesia, cet.1, Jakarta: Akademi Presindo.

Basyir, Ahmad Azhar,2001, Hukum Perkawinan Islam, cet. 8. Yogyakarta: UII Press. ,1983, Hukum Adat Bagi Umat Islam, cet.1, Yogyakarta: F.H. UII.

-32000, Asas-Asas Hukum
Mu'amalat, Yogyakarta, UII Press.

Dawaliby, Muhammad Ma'ruf Ad,1985, AlMadhkhah Ila-IImi Ushul Fiqih, cet.5, Damaskus, Darul Kutub.

Hadi Suprapto, SH,Hartono,, 1988, Pengantar Tata Hukum Indonesia, ed. 2 Yogyakarta, Liberty.

Hanafi MA, Ahmad,1984, Pengantar dan Sejarah Hukum Islam, cet.3, Jakarta: Bulan Bintang.

Ibnul Qoyyim, I' lamul Muwaqiin, Juz 3, Beirut: Darul Jail, t.t.
Al-Khallaf, Abdul Wahhab,1950, ljtihad bin Ra'yi, Mesir,Darul Fikr. 1982, Mashadirul Islami Fi ma laNashshaffhi, cet.5, Kuwait, Danul Qalam.

An-Nawawy, Yahaya bin Syarifuddin, Matan al-Arba'in an-Nawawiyah,t.t., Carbon: Syirkah Mathba'ah, Indonesia.

Rozak, Nasruddin,1972 Darul Islam, Surabaya: Al-Ma'arif.

Rofiq, Ahmad,2001, Hukum Islam di Indonesia, Yogyakarta, Gama Media.

Sosro Atmojo, H.Arso, t.t., Hukum Perkawinan di Indonesia, Jakarta, Mutiara.

Syarifuddin, Amir, 1990, Pembaharuan Pemikiran dalam Hukum Islam, Padang: Angkasa Raya.

Rahman, Asymuni.A, 1976 Qa'idahqa'iadah Fighyah, cet.1, Jakarta: Bulan Bintang.

Ash-Shiddieqy, Hasbi, 1978, Pengantar Hukum Islam, Jakarta:Bulan Bintang. 1975, Falsafah Hukum /slam, Jakarta: Bulan Bintang.

As-Suyuthi, Jalaiuddin, 1960, Al-Asybah Wan Nahdza'ir, cet. 3, Mesir Amin Abdul Madjid.

Zahrah, Abu, Ushul Fiqih, Kairo: Darul Fikr, al-Arabiyah, $\mathrm{t}, \mathrm{t}$.

Tabloid Jum'at, 4 April 2003.

Republika, Jum'at, 17 Mei 2003. 